\title{
Evaluation of the cytotoxic anticancer effect of polysaccharide of Nepeta septemcrenata
}

\author{
Sawsan Ahmed Nasr ${ }^{1 *}$ and Amel Abd El-Moneim Saad ${ }^{2}$
}

\begin{abstract}
Background: Promoting cancer cells apoptosis is one of the effective methods to treat cancer. Human hepatocelIular carcinoma (HepG2) and colorectal cancer (HCT-116) cell lines were used in the present study to evaluate the cytotoxic and anticancer properties of Nepeta septemcrenata Polysaccharide (NSP).

Result: Treatment of the two examined cells with NSP displayed a significant cytotoxicity towards HepG2 in a dosedependent manner; meanwhile, its effect on HCT-116 was obtained under the influence of low doses. The quantitative real- time PCR (QRT-PCR) investigation revealed that NSP significantly up-regulated the expression levels of p53, p16, Fas, Fas-L, Bax, caspases-3, caspase-9, and TNF-a in association with down-regulation of cyclin D1, TERT, and $B C L 2$. These findings declare the apoptotic characteristic of NSP.NSP, can also inhibit the development of cancer cells through the down-regulation of TGF- $\beta$ and VEGF.
\end{abstract}

Conclusions: Our results suggested that the polysaccharides isolated from N. septemcrenata possess anticancer properties that could be explored for the development of novel anticancer agents.

Keywords: Anticancer, Polysaccharide, HepG2 and HCT-116

\section{Background}

Cancer is one of the most serious diseases attacking human in the few preceding decades throughout the world [1]. In 2017, about 9.6 million people died due to various types of cancer which are nearly equal about sixth of number of the dead i.e. cancer is the second cause of death. Economically, Cancer is detrimental to development and harms the economy [2]. Drugtherapy efficiency suffers many problems like its high specificity of cancer cell type and the induction of drug resistance $[3,4]$. Hepatocellular carcinoma (HCC) is recorded as one of the most cancer-related mortalities in the world [5]. Liver is the common organ subjected to metastasis in patients of colorectal cancer (CRC). Colon cancer is a destructive and fast-growing malignant massive tumor arising from the inner wall of the large intestines. Hepatic

\footnotetext{
*Correspondence: sawsannasr2@gmail.com

1 Physiology Department, Egyptian Drug Authority, Formerly Known as National Organization for Drug Control and Research, Giza, Egypt Full list of author information is available at the end of the article
}

metastases are about of $60 \%$ of the patients who died by colorectal cancer, which is attributed to liver failure. Up to $18 \%$ of CRC' patients; under first investigation; showed metastasis, while this percentage raised up to $35 \%$, when computed tomography (CT) was applied [6].

Chemotherapy and radiation are used before or after surgery in treatment of certain types of cancer such as colorectal treatment. However, with these treatments, severe gastrointestinal toxicity, with diarrhea and mucosis, and hematological toxicity, with leucopenia and immune suppression, appear to be dose-limiting factors. Furthermore, the toxicity produced by chemotherapy afflicts on system of cancer patients [7].

Many pharmacological studies were applied to discover new inhibiting cancer cell agents such as polysaccharide from many herbaceous plants [8]. Such polysaccharides are natural products with acts as anti-cancer activity that are widely present during a lot of plants. Many studies recorded that these polysaccharides induce apoptosis mechanism of cancer cells [9]. 
Nepeta species are widely applied in folk medicine for their antispasmodic, expectorant, diuretic, antiseptic, antitussive, antiasthmatic, and febrifuge activities [10]. Nepeta septemcrenata (Family: Lamiaceae) is employed in folk medicine as antipyretic, sedative, cardiotonic, and eye wash also as a gargle for pharyngitis [11]. Previously, we isolated polysaccharides from the aerial parts of N. septemcrenata and we reported that the isolated polysaccharides contain Arabinose 25.15\%, Xylose $11.10 \%$, Ribos $2.7 \%$, Rhamnose 8.3\%, Mannitol 0.97\%, Sorbitol 1.34\%, Galactose-mannose 18.48\%, Glucose 22.74\%, and Glucoronic acid 9.1\% [12].

Regarding to this previous work; that demonstrated the antioxidant potential of polysaccharide extracted from the aerial parts of N. septemcrenata (NSP); the present study was conducted to evaluate whether NSP displays growth inhibition activity and induces apoptosis in human hepatocellular carcinoma HepG2 cells and human colorectal cancer cell line HCT-116, and we provide evidence that NSP can be used as a potent anti-cancer agent to treat liver and colon cancer with the sensitivity of the colon cancer to the low doses of NSP.

\section{Methods}

\subsection{Preparation of plant extract and the extraction of polysaccharides}

Polysaccharide was extracted from the dry tissue of Nepeta septemcrenata. Tissue was defatted by petroleum ether [12]. Polysaccharide was extracted by $95 \%$ ethyl alcohol [13] and then analyzed by $\mathrm{HCl}$ technique [14].

\subsection{Cell lines}

Human liver and colon cancer cell lines; particularly HepG2 and HCT-116, were obtained from the American Tissue Culture Center (ATCC) and employed in the current study.

\subsection{Cell culture and cytotoxicity assay}

To determine the inhibitory effect of NSP on HCT-116 and HepG2 cell proliferation, the two cell lines were exposed to the isolated NSP in different concentrations for $48 \mathrm{~h}$.

The potential cytotoxicity of $N$. septemcrenata was assayed by using Sulforhodamine B (SRB) [15] as the following:

1. Human hepatocellular carcinoma (HepG2) and colorectal carcinoma (HCT-116) cell lines were plated in 96-multiwell plates $\left(10^{4}\right.$ cells/well $)$ for $24 \mathrm{~h}$. before treatment with $N$. septemcrenata polysaccharides to allow attachment of cells to the wall of the plate. Different concentrations of $N$. septemcrenata polysaccharides $(0,20,40$, and $60 \mu \mathrm{g} / \mathrm{ml})$ were added to the cell monolayer triplicate wells and were prepared for each individual dose.

2. Monolayer cells were incubated with $N$. septemcrenata polysaccharides for $48 \mathrm{~h}$ at $37^{\circ} \mathrm{C}$ and in an atmosphere of $5 \% \mathrm{CO}_{2}$.

3. After $48 \mathrm{~h}$, cells were fixed with $50 \%$ trichloroacetic acid (TCA), washed with water to remove residues of TCA, and stained for 30 min with $0.4 \%$ Sulforhodamine- B (SRB) stain (prepared in $1 \%$ acetic acid).

4. Excess stain was washed with $1 \%$ acetic acid and attached stain was recovered by Tris-EDTA buffer (trihydroxymethyl aminomethane-ethylene diamine tetra acetic acid).

5. Color intensity was measured in an ELISA reader at $540 \mathrm{~nm}$.

6. The relation between surviving fraction and N. septemcrenata polysaccharides is plotted to get the survival curve of each tumor cell line.

\subsection{DNA fragmentation}

The protocol of agarose gel electrophoresis [16] was applied to isolate DNA. In brief cell lines (treated and untreated) lysed 10 mMTris (pH 8), 20 mM EDTA, 200 $\mathrm{mMNaCl}, 0.2 \%$ TritonX-100, and $100 \mu \mathrm{g} \mathrm{ml}^{-1}$ Proteinase K. $250 \mu \mathrm{g} / \mathrm{ml}$ of RNase impulsive DNA then electrophoresis in $1.0 \%$ agarose gel divide DNA fragments $(10 \mu \mathrm{g}$ of total DNA) and finally visualized using ethidium bromide staining $(0.5 \mathrm{mg} / \mathrm{ml})$ and $\mathrm{UV}$ trans-illuminator.

\subsection{RNA extraction}

Cells of all studied groups were lysed and total RNA was isolated with RNA easy Mini Kit (Qiagen) and further analyzed for quantity and quality with Beckman dual spectrophotometer (USA). The kit was provided by Thermo Fisher Scientific Inc. Germany. (GeneJET, Kit, \#K0732) [17, 18].

\subsection{RT-PCR for p53, p16, cyclinD1, hTERT, Fas, Fas-L, Bax,}

BCL-2, caspase-9, caspase-3, TNF- $\alpha$, TGF- $\beta$, and VEGF

$10 \mathrm{ng}$ of the total RNA from each sample was used for cDNA synthesis by reverse transcription using HighCapacity cDNA Reverse Transcriptase Kkit (Applied Biosystem, USA). The quality of cDNA was assessed by amplifying an internal reference gene, $\beta$-actin, by PCR and $2 \%$ agarose gel electrophoresis were confirmed the results. A computerized gel imaging system (Bio-Rad, Hercules, CA, USA) used to examine the products.

Quantitative RT-PCR was conducted as follows: the cDNA was subsequently amplified with the Syber Green I PCR Master Kit (Fermentas) [16] in a 48-well plate using the Step One instrument (Applied Biosystem, USA) as follows: $10 \mathrm{~min}$ at $95{ }^{\circ} \mathrm{C}$ for enzyme activation followed 

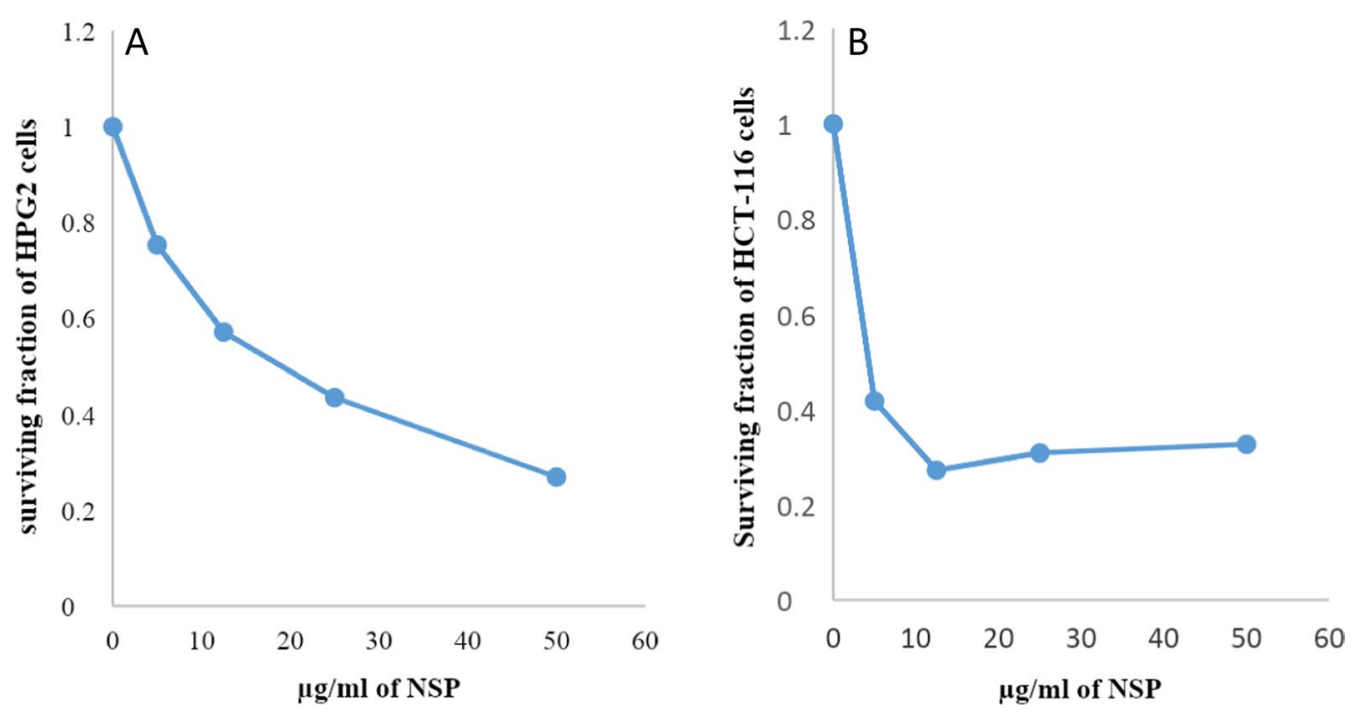

Fig. 1 Cytotoxicity effect of N. septemcrenata on human cell line of human cell line of HepG2 and HCT-116

by 40 cycles of $15 \mathrm{~s}$ at $95{ }^{\circ} \mathrm{C}, 20 \mathrm{~s}$ at $55^{\circ} \mathrm{C}$, and $30 \mathrm{~s}$ at $72{ }^{\circ} \mathrm{C}$ for the amplification step. Changes in the expression of each target gene were normalized relative to the mean critical threshold (CT) values of $\beta$-actin as housekeeping gene by application of the $\Delta \Delta \mathrm{Ct}$ method [19]. We used $1 \mu \mathrm{M}$ of both primers specific for each target gene. Primers sequence and annealing temperature specific for each gene are demonstrated in Table 1.

\subsection{Statistical analysis}

The results were expressed as mean values \pm standard error (mean $\pm \mathrm{SE}$ ). Difference between the control group and the treated one was assessed using independent t-test. Data were statistically analyzed using the Statistical Package of Social Science (SPSS) version 23.

\section{Results}

\subsection{N. septemcrenata polysaccharides (NSP) exert anti} proliferative effects on HCT-116 and HepG2 cells

NSP exhibited a marked growth-inhibitory effect on HepG2 and HCT- 116 cells with $\mathrm{IC}_{50} 4.28$ and $19.3 \mu \mathrm{g} /$ $\mathrm{ml}$ for HepG2 and HCT-116, respectively (Fig. 1; A and B). The obtained data revealed that the inhibitory effect of NSP on HepG2 is displayed in a dose- dependent manner; meanwhile, its effect on HCT-116 cells is efficiently displayed with a low dose of NSP.

\subsection{Apoptosis detection by DNA agarose gel electrophoresis}

The apoptotic process results in fragmentation of genomic DNA in characteristic oligonucleosomal fragments. DNA from treated and untreated HepG2 and

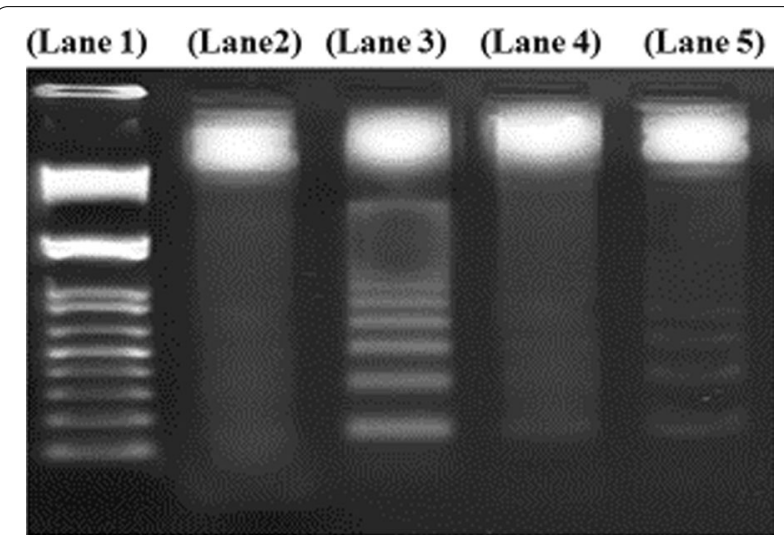

Fig. 2 DNA fragmentation in HepG2 and HCT-116 cells treated with NSP for 48 h; lane 1: DNA laddering, lane 2: HepG2 untreated control cells, lane 3: HepG2 treated cells, Lane 4: HCT-116 untreated cells

HCT-116 cells was isolated and subjected to agarose gel electrophoresis (Fig. 2). Cells treated for $48 \mathrm{~h}$ with 19. 3 and $4.28 \mu \mathrm{g} / \mathrm{ml}$ of NSP showed a typical DNA ladder on agarose gels compared to untreated control cell lines. The observed DNA fragmentation is more apparent in treated HepG2 cells than that in HCT-116.

\subsection{N. septemcrenata polysaccharides activates the expression of p53 and p16 as well as down-regulates the expression levels of cyclin D1 and hTERT in HepG2 and HCT-116 cells}

The QRT-PCR revealed that NSP significantly increased the expression levels of p53 and p16 in HepG2 and HCT116 cells relative to untreated cells (Fig. 3A-D). On 


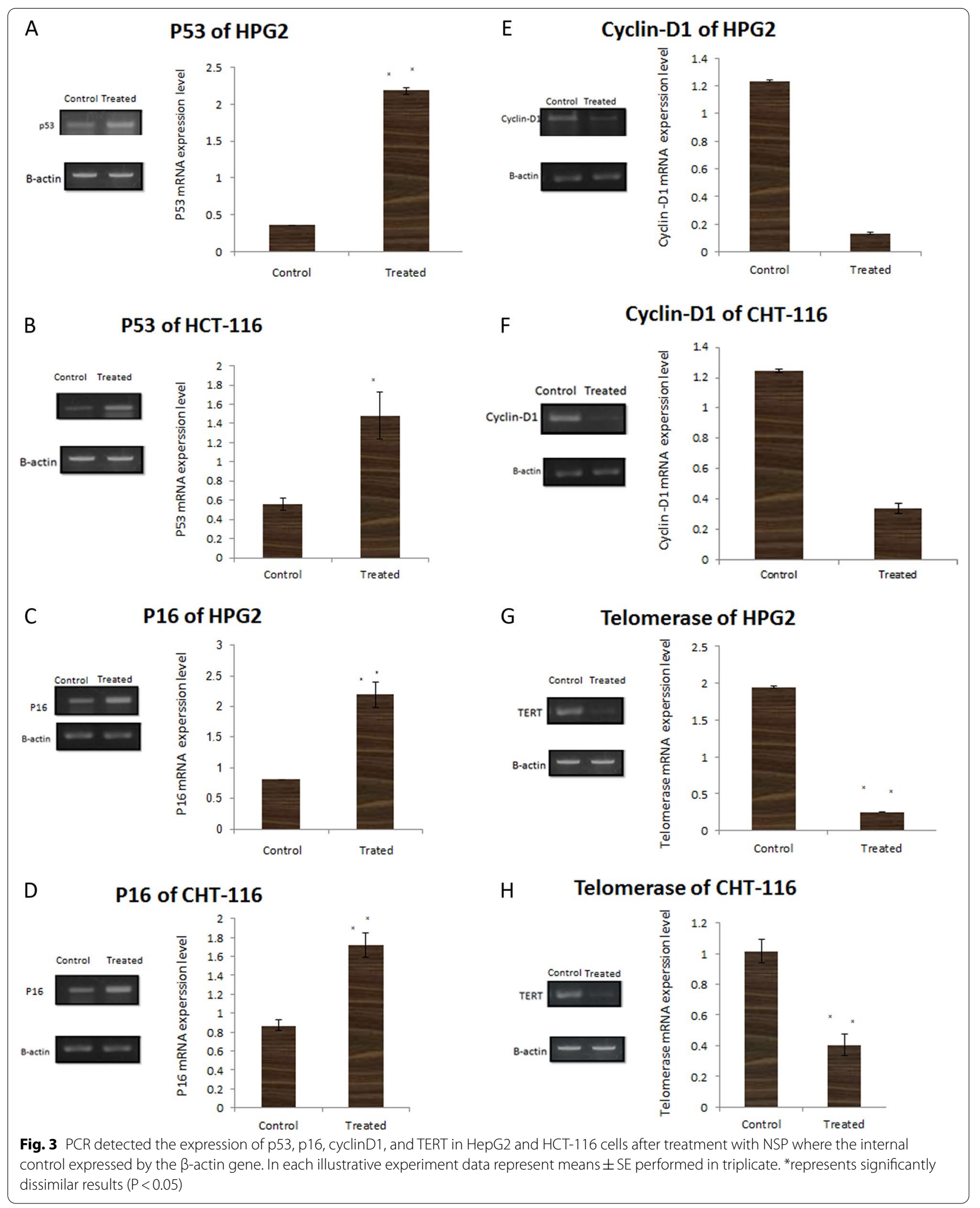




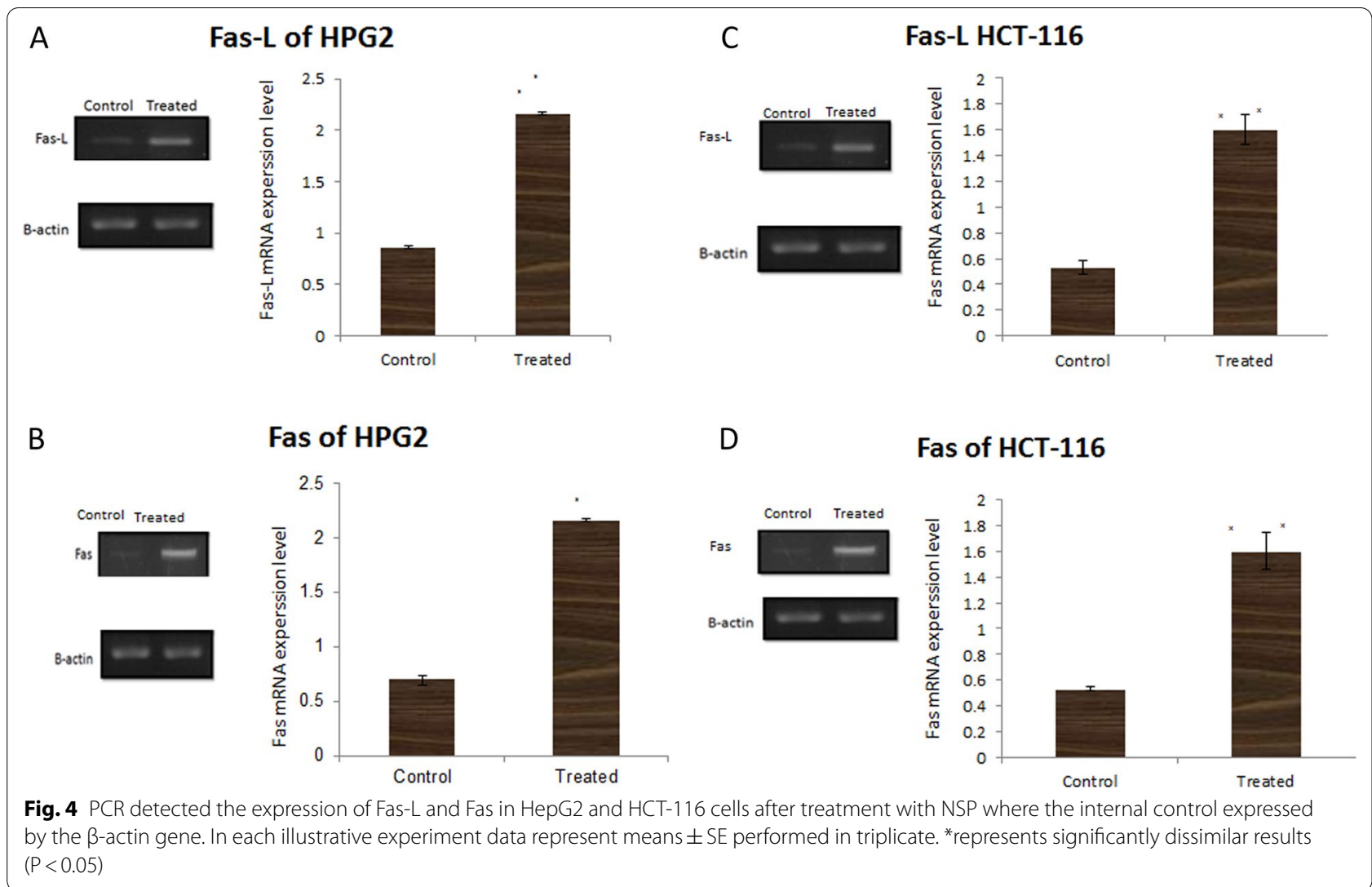

the other hand, Fig. 1E-H show that NSP significantly decreased the mRNA expression levels of cyclin-D1 and hTERT in the two examined cell lines. The obtained data also revealed that NSP treatment induced a more pronounced effect in decreasing the expression levels of cyclin D1 and hTERT in HepG2 cells than that induced in HCT-116 cells.

\subsection{NSP induces apoptosis via Fas/Fas-L dependent apoptosis pathway in HCT-116 and HepG2 cells}

The obtained results revealed that the isolated NSP increased the mRNA expression levels of Fas and Fas-L in the two examined cell lines as shown in Fig. 4A-D when compared with the untreated cells.

\subsection{NSP induces apoptosis through activation of intrinsic mitochondrial signaling pathway}

There was a significant increase in the mRNA expression levels of Bax in HepG2 and HCT-116 cells treated with NSP for 48 h, (Fig. 5A, B). Inversely, Bcl-2 mRNA expression levels in HepG2 and HCT-116 cells were significantly reduced in response to NSP treatment (Fig. 6A, B). My data also revealed a well-marked up-regulation in the expression levels of caspase- 9 and caspase- 3 in the two examined cell lines (Fig. 7A-D).

\subsection{Effect of NSP on TNF- $\alpha$, VEGF, and TGF- $\beta$}

The treatment of HepG2 and HCT-116 cell lines with NSP for $48 \mathrm{~h}$ elicited that TNF- $\alpha$ Level of mRNA expression increase significantly in comparison with the untreated cells. The obtained results revealed that the content of the expressed TNF- $\alpha$ is approximately the same in the two examined cell lines (Fig. 8A, B). Meanwhile, the two examined cells of TGF- $\beta 1$ and VEGF their expression levels decreased significantly in comparison of the control untreated cells as seen in Fig. 9A, B and Fig. 10A, B. NSP displayed a decreasing effect on TGF- $\beta 1$ and VEGF expression levels in HepG2 cell lines less than that induced in HCT-116 cells.

\section{Discussion}

The present work showed that, the polysaccharides isolated from N. septemcrenata (NSP), inhibited, in vitro, the growth of HepG2 and HCT-116 cell lines via anti proliferative impact. Such mechanism was investigated by different polysaccharides such as those of peony seed [20], Scutellaria barbata grass [21] and Panax ginseng root $[22,23]$. The obtained results demonstrated that the inhibitory effect of NSP on HepG2 is more pronounced and displayed in a dose-dependent manner; meanwhile, 


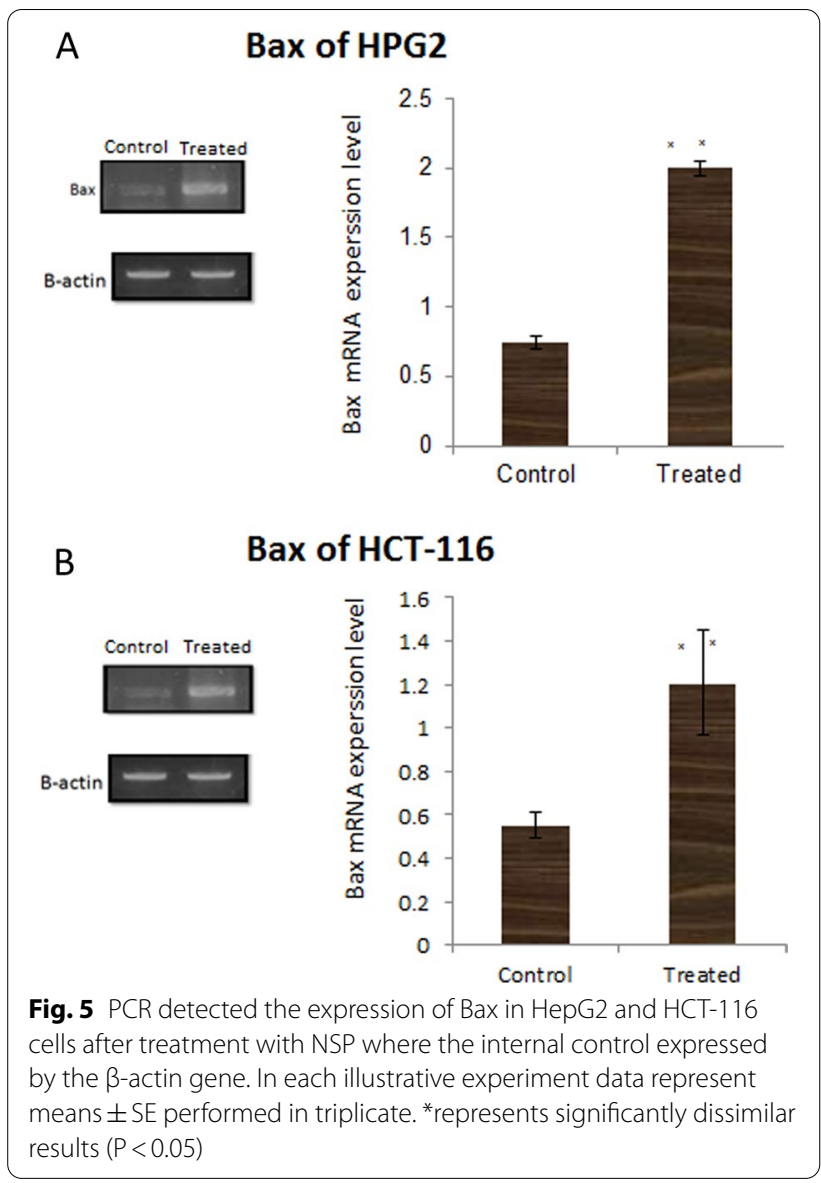

HCT-116 growth inhibition is sensitive to the lower doses of NSP.

NSP promoted the apoptosis of cancer cell and this investigation is consistent with many other results [2427]. Such promotion is an effective method to treat cancer [24] and a main chemotherapy mechanism of which cancer treatment [25-27]. DNA fragmentation may be an indicator of apoptosis as well as it facilitates apoptosis by terminating DNA replication and gene transcription [28]. Treatment of HepG2 and HCT-116 cell lines with 19.3 and $4.28 \mu \mathrm{g} / \mathrm{ml}$ of NSP for $48 \mathrm{~h}$ resulted in DNA fragmentation in the isolated DNA from the two examined cells. The investigated DNA fragmentation was greater in HepG2 than in HCT-116 cells. This finding agrees the data of cell viability and confirming the induction of apoptosis.

QRT-PCR was used in the present study to evaluate the possible mechanism responsible for the growth inhibition and cell apoptosis that is observed by NSP treatment. The obtained data revealed that, treatment of HepG2 and HCT-116 with NSP displayed a well-marked elevation in the expression levels of p53 and p16, with down-regulation of cyclin D1 mRNA and hTERT. These data agrees

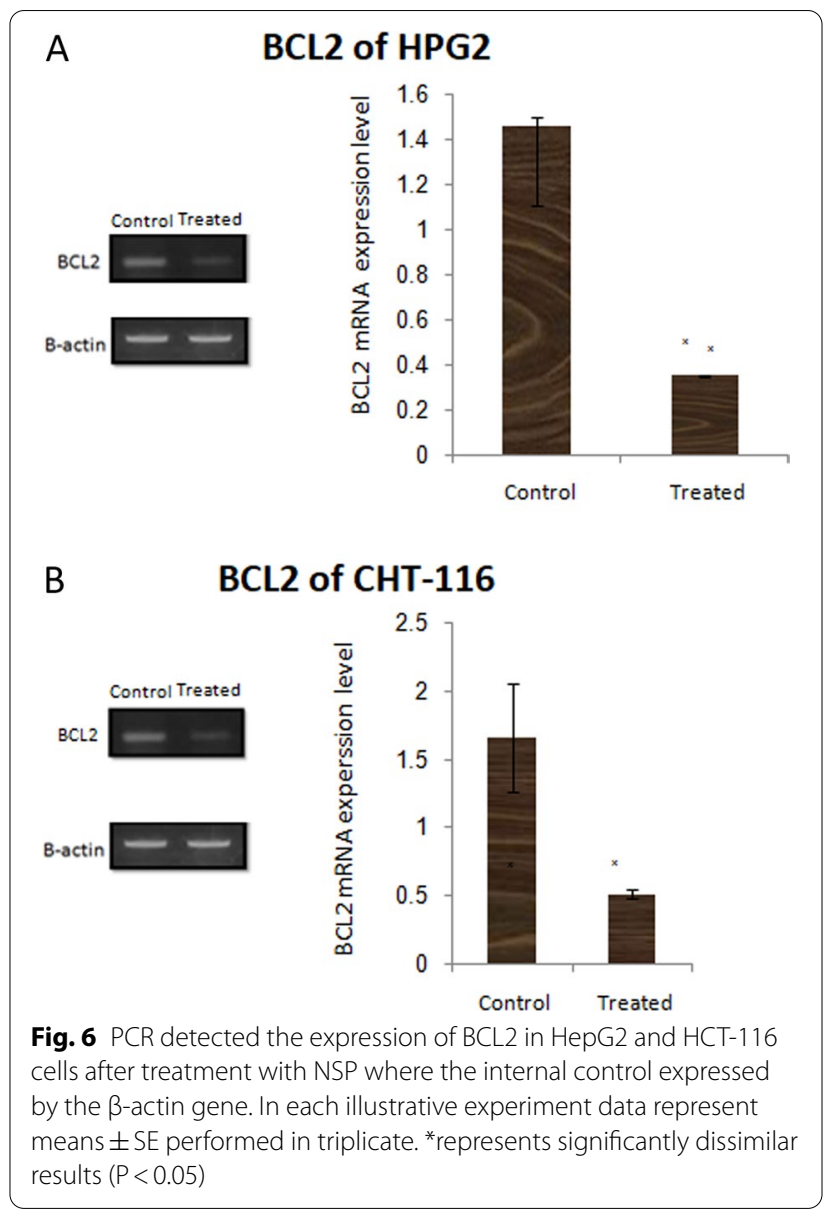

with data demonstrated by Senturk and Manfredi [29]. Both of growth inhibition and induced apoptosis of the cells due to treatment with NSP indicate the accuracy of NSP for inducing cell cycle arrest inducing of tumor suppressor genes p53 and p16. These two genes regulate the cell cycle through specific mechanisms. P53 adjusts the cell cycle at $\mathrm{G} 1$ checkpoint which was stimulated by DNA damage [29]. It has been noticed that, P16 acts as a tumor suppressor gene via its genetic inactivation in a variety of human cancers [30], for instance, for HCC ([31] and [32]). P16 is also can induce cell cycle arrest in the G1 phase [33]. It has been reported that the downregulation of cyclin D1 pointed to the cell cycle arrest at the G1/S transition, with subsequent p53-independent apoptosis in human cancer cells [34].

It has been observed that telomerase is significantly more active in cancer cells and practically undetectable in normal cells so, it may be used as a selective target in cancer therapy. Its inhibition would selectively suppress tumor growth without considerable effects on normal cells [35]. In the present work, in the two surveyed cancer cell lines, the mRNA expression level of hTERT was 

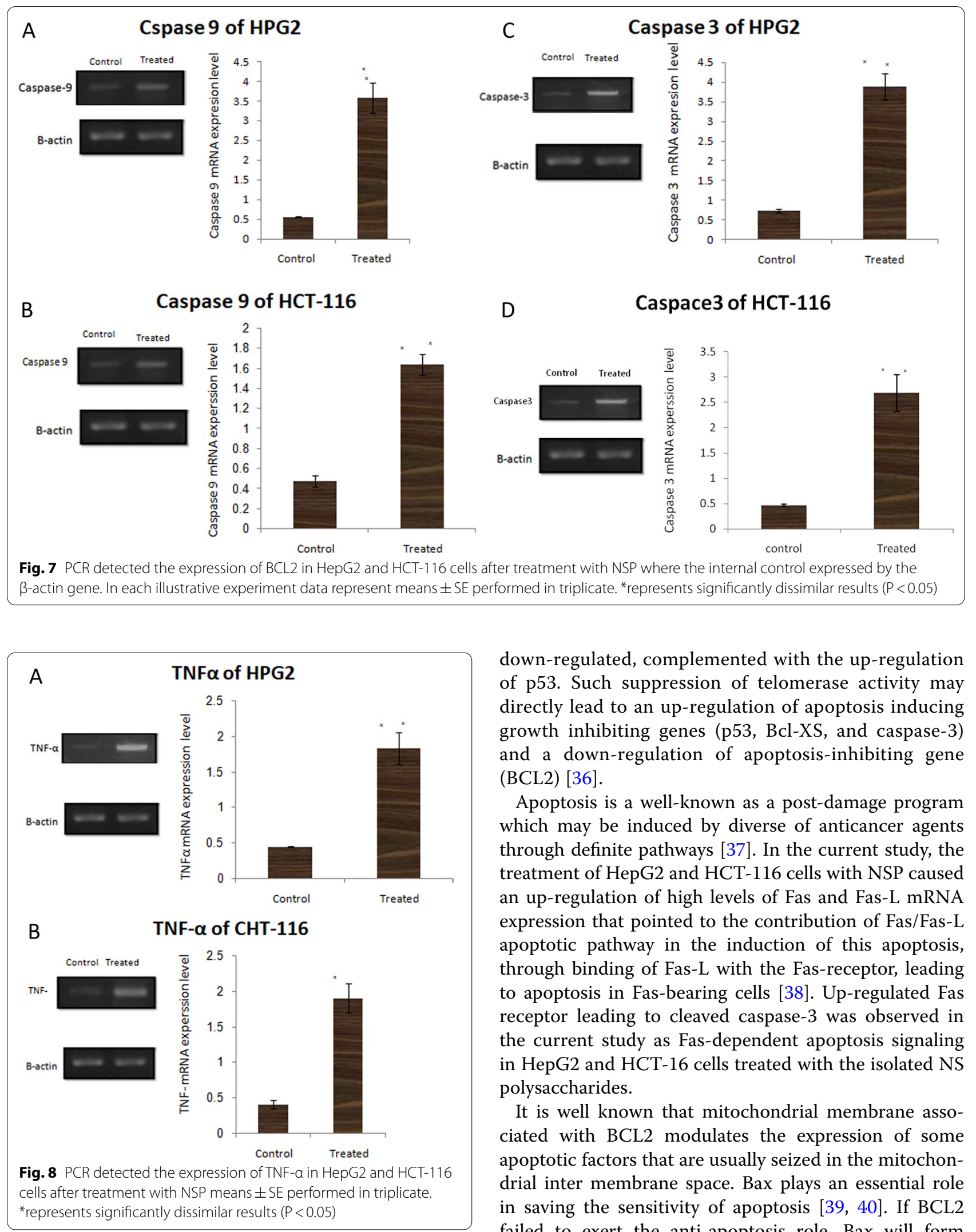

down-regulated, complemented with the up-regulation of p53. Such suppression of telomerase activity may directly lead to an up-regulation of apoptosis inducing growth inhibiting genes (p53, Bcl-XS, and caspase-3) and a down-regulation of apoptosis-inhibiting gene (BCL2) [36].

Apoptosis is a well-known as a post-damage program which may be induced by diverse of anticancer agents through definite pathways [37]. In the current study, the treatment of HepG2 and HCT-116 cells with NSP caused an up-regulation of high levels of Fas and Fas-L mRNA expression that pointed to the contribution of Fas/Fas-L apoptotic pathway in the induction of this apoptosis, through binding of Fas-L with the Fas-receptor, leading to apoptosis in Fas-bearing cells [38]. Up-regulated Fas receptor leading to cleaved caspase- 3 was observed in the current study as Fas-dependent apoptosis signaling in HepG2 and HCT-16 cells treated with the isolated NS polysaccharides.

It is well known that mitochondrial membrane associated with BCL2 modulates the expression of some apoptotic factors that are usually seized in the mitochondrial inter membrane space. Bax plays an essential role in saving the sensitivity of apoptosis [39, 40]. If BCL2 failed to exert the anti-apoptosis role, Bax will form a channel in the mitochondrial outer membrane that 


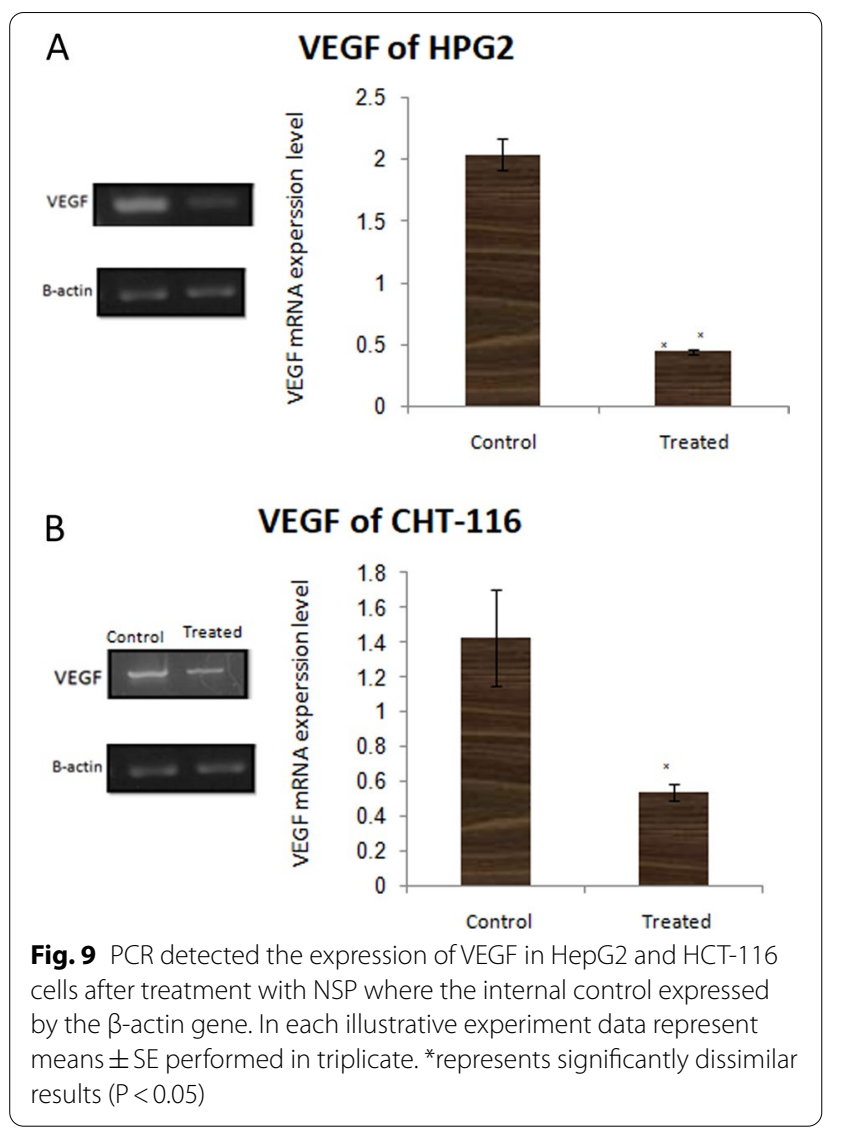

facilitates apoptosis through the initiation of mitochondria-mediated (intrinsic) apoptotic pathway [41]. This pathway is initiated by the up-regulation of caspase-9, followed by apoptosis enforcement by caspase- 3 which

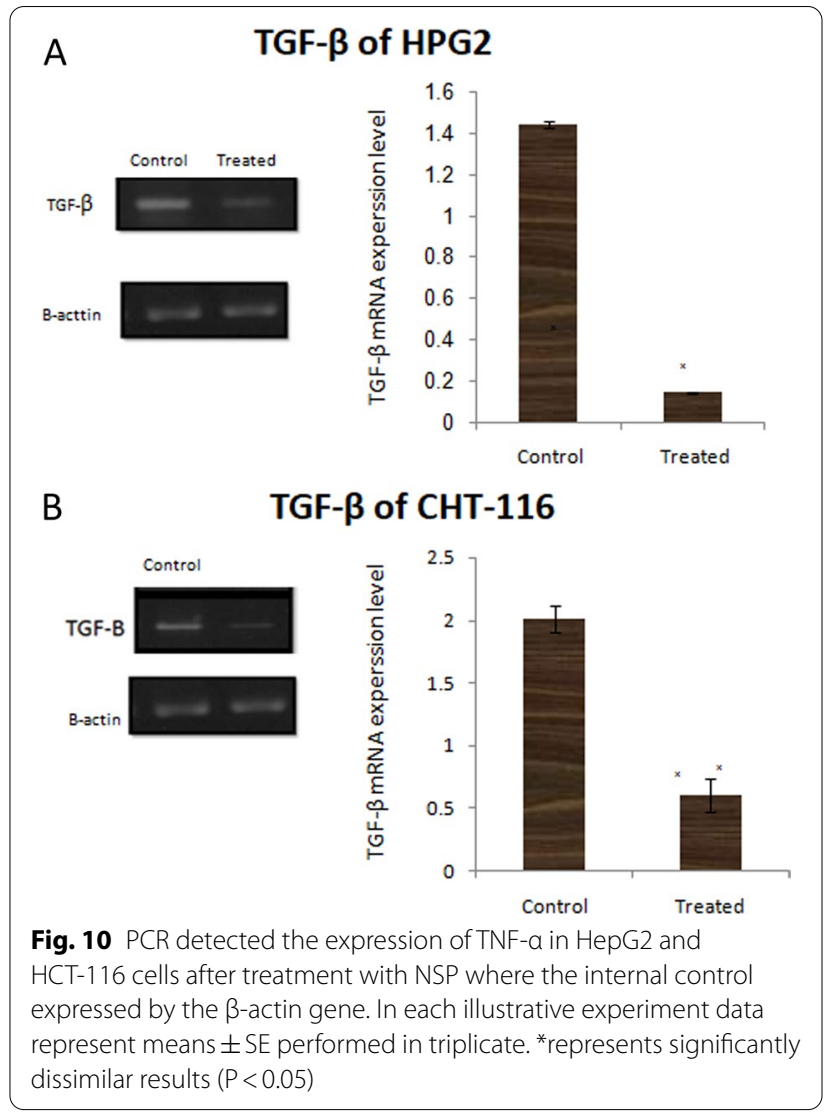

is activated by caspase- 9 . The obtained reduction of Bcl-2 mRNA expression levels, with the elevation of Bax and caspase-9 mRNA expression levels in HepG2 and HCT- 116 indicates that the mitochondrial-dependent

Table 1 Primers sequence for RT-PCR

\begin{tabular}{|c|c|}
\hline Target gene & Primer sequence: $5^{\prime}-3^{\prime}$ \\
\hline P53 & F: GCAACGGAACACTCTCCATATTTT. R: CAGAGAAGAAACGGTAGCAGAAGA \\
\hline P16 & F: CATTCGCTAAGTGCTCGGAGT. R: CTCCTCTTTCTTCCTCCGGTG \\
\hline Cyclin -D1 & F: GGAAAGCTTCATTCTCCTTGTTG. R: TCTAGGTAAACCTCTGAGGTCC \\
\hline TERT & F:TACGTCGTGGGAGCCAGAAC. R: CCTTCACCCTCGAGGTGAGA \\
\hline Fas & F:TCTTTCACTTCGGAGGATTGCT. R:ACTTTCTGTTCTGCTGTGTCTT \\
\hline Fas-L & F: GGTCCATGCCTCTGGAATGG. R:CACATCTGCCCAGTAGTGCA \\
\hline BCL2 & F: ATGGCGCACGCTGGGAGAAC. R: GCGGTAGCGGCGGGAGAAGT \\
\hline Bax & F:TTCATCCAGGATCGAGCAGG. R: CTCTGCAGCTCCATGTTACT \\
\hline Caspase-9 & F:TACAGCTGTTCAGACTCTAGTA. R: AAATATGTCCTGGGGTAT \\
\hline Caspase-3 & F:TGACAGCCAGTGAGACTTGG. R: GACTCTAGACGGCATCCAGC \\
\hline TNF-a & F: ATCCGGGACGTGGAGCTG. R:AAAGTAGACCTGCCCAGAC \\
\hline TGF- $\beta$ & F: AACACATCAGAGCTCCGAGAA. R: GTCAATGTACAGCTGCCGCAC \\
\hline VEGF & F: CGGGAACCAGATCTCTCACC. R: AAAATGGCGAATCCAATTCC \\
\hline$\beta B$-actin & F: GGC GGCACCACCATGTACCCT. R: AGG GGCCGGACTCGTCATACT \\
\hline
\end{tabular}

$F$ : is a primer for forward. $R$ : is a primer for reverse 
apoptosis pathway was activated in HepG2 and HCT-116 cells treated with NSP. Consistent with our findings, several studies confirmed the role of plant polysaccharides in initiating both extrinsic and intrinsic apoptosis pathways in liver and colorectal cancer cells [20,42].

It has been reported that there is a group of stimulating stresses like growth factor withdrawal and heat shock as well as oxidative damage, that have been investigated, activated the apoptosis either intrinsic or mitochondrial pathway [43-45]. Cytokines has an essential role in the initiation and development of tumors and their therapy [46]. Tumor necrosis factor (TNF- $\alpha$ ) is a significant cytokine of anti-tumor agent; it acts as a growth inhibitor and direct cytotoxic attacking tumor + cells. It can directly suppress and destroy tumor cells, induce cell apoptosis, facilitate the immune response, and inhibit the tumor angiogenesis that may be explained collectively, its anti-tumor function [47, 48]. In the present study, the increased TNF- $\alpha$ mRNA expression may also be an important molecular target for NSP-induced apoptosis in liver and colorectal cancer.

TGF- $\beta$ is a multifunctional cytokine which is elaborated within the regulation of apoptosis of many cell types and is concerned within the pathogenesis of human diseases, like carcinogenesis. The VEGF family has a crucial role in tumor angiogenesis and is contributed with solid tumor growth and metastasis [9]. Many studies have been observed that, the dark mushroom (Ganoderma lucidum) polysaccharide (GLP) can inhibit angiogenesis and suppresses VEGF over expression and tumor angiogenesis, in vitro, in metastatic mouse melanoma B16F10 cells [49].

Data of the present work investigated that the effect of NSP on the mRNA expression levels of TGF- $\beta$ and VEGF may confirm their participation in the HCC and colorectal cancer occurrence and development [50]. Application of NSP, significantly, reduced TGF- $\beta$ and VEGF mRNA expression levels which may prove that, these two growth factors may be negatively convoluted in the cancer cell apoptosis. This demonstration is in agreement with many studies that discussed the inhibiting influence of plant polysaccharides on the expression levels of TGF- $\beta$ and VEGF through the low expression of their receptors on the cell surface [51].

The obtained results confirmed that NSP suppressed angiogenesis directly via inhibition of cell proliferation, and induction of cell death in vascular endothelial cells, and indirectly by retarding of VEGF production in tumor cells.

\section{Conclusions}

In this study, we found that $N$. septemcrenata polysaccharide (NSP) displays significant cytotoxicity towards HepG2 cells in a dose-dependent manner; meanwhile, its effect on HCT-116 is obtained under the influence of low dose of NSP. These findings demonstrate that the apoptotic effect of NSP is mediated through both extrinsic and intrinsic apoptotic pathways in HepG2 and HCT-116 cells. Therefore, we propose that NS polysaccharide possesses anti-cancer properties, whose potential should be explored for the development of novel anticancer agents under in vivo conditions by choosing suitable animal models followed by clinical trials.

\section{Abbreviations \\ HepG2: Human hepatocellular carcinoma; HCT-116: Colorectal cancer; NSP: Nepeta septemcrenata Polysaccharide; QRT-PCR: Quantitative real- time PCR; CRC: Colorectal cancer; ATCC: American Tissue Culture Center; SRB: Sulfo-Rho- damine B; TCA: Trichloroacetic acid; CT: Critical threshold; mean \pm SE:: Mean values \pm standard; SPSS: Statistical Package of Social Science; TNF-a: Tumor necrosis factor; GLP: (Ganoderma lucidum) Polysaccharide.}

\section{Acknowledgements}

We Acknowledgements Dr Nadia EL-tablawy for her contributions in reviewing this manuscript.

\section{Authors' contributions}

$\mathrm{SN}$ : design of the work, created of new software used in the work and drafted the work substantively. The two authors in this manuscript do experimental section with us. AS: did the statically analysis and revised the work. Both authors read and approved the final manuscript.

Funding

Not applicable.

Availability of data and materials

Not applicable. Our data will not be shared because it's private to us.

\section{Declarations}

Ethics approval and consent to participate Not applicable.

Consent for publication

Not applicable.

\section{Competing interests}

The authors declare that they have no competing interests.

\section{Author details}

${ }^{1}$ Physiology Department, Egyptian Drug Authority, Formerly Known as National Organization for Drug Control and Research, Giza, Egypt. ${ }^{2}$ Biochemistry Department, Egyptian Drug Authority, Formerly Known as National Organization for Drug Control and Research, Giza, Egypt.

Received: 28 April 2021 Accepted: 8 August 2021

Published online: 07 September 2021

References

1. Nandini G, Anil KM, Mittal S (2014) Essential oils and their constituents as anticancer agents: a mechanistic view. Hindawi BioMed Res Int 2014:154106

2. Ferlay J, Soerjomataram I, Dikshit R, Eser S, Mathers C, Rebelo M, Parkin DM, Forman D, Bray F (2015) Cancer incidence and mortality worldwide: sources, methods and major patterns in GLOBOCAN 2012. Int I Cancer 136(5):E359-E386. https://doi.org/10.1002/ijc.29210

3. Gottesman MM (2002) Mechanism of cancer drug resistance. Annu Rev Med 53:615-627 
4. Turan I, Demir S, Misir S, Kilinc K, Mentese A, Aliyazicioglu Y, Deger O (2015) Cytotoxic effect of Turkish propolis on liver, colon, breast, cervix and prostate cancer cell. Lines Trop J Pharmaceut Res 14(5):777-782

5. Rashed WM, Kandeil MAM, Ezzat MO (2020) Hepatocellular Carcinoma (HCC) in Egypt: a comprehensive overview. J Egypt Natl Canc Inst 32:5

6. Valderrama-Treviño Al, Barrera-Mera B, Ceballos-Villalva JC, Montalvo-Javé EE (2017) Hepatic metastasis from colorectal cancer. Eur J Hepatogastroenterol 7(2):166-175

7. Aprile G, Rihawi K, De Carlo E, Sonis ST (2015) Treatment-related gastrointestinal toxicities and advanced colorectal or pancreatic cancer: A critical update. World J Gastroenterol 21(41):11793-11803

8. Liang Z, Guo YT, Yi YJ, Wang RC, Hu QL, Xiong XY (2014) Ganodermalucidum polysaccharides target a Fas/caspase dependent pathway to induce apoptosis in human colon cancer cells. Asian Pac J Cancer Prev 15(9):3981-3986

9. Gan Q, Wang J, Hu J, Lou G, Xiong H, Peng C, Huang Q (2020) Modulation of apoptosis by plant polysaccharides for exerting anti-cancer effects: a review. Front Pharmacol 11:792

10. Abd El-Moaty HI (2010) Essential oil and iridoide glycosides of Nepeta septemcrenata Erenb. J Nat Prod 3:103-111

11. Abdel-Shafiq KA (1997) Chemical studies on certain plants of family Labiate. M. Sc. thesis, Chemistry Dep. Faculty of Science, Cairo University, 174 $\mathrm{pp}$

12. Nasr SA, Saad AA, Khader MS (2015) Role of Polysaccharides isolated from Nepeataseptemcrenata in diabetic albino rats. Journal of Biomedical and Pharmaceutical Research 4(4):140-151

13. Ronald SK, Ronald S (1991) Pearson's composition and analysis of foods subsequent edtion. Longman Scientific and Technical, London, pp 182-235

14. Stahl E (1969) Thin layer chromatography, 2nd edn. Springer, Bern, pp 366-367

15. Skehan P, Storeng R, Scudiero D, Monks A, McMahon J, Vistica D, Warren JT, Bokesch H, Kenney S, Boyd MR (1990) New colorimetric cytotoxicity assay for anticancer-drug screening. J Natl Cancer Inst 82(13):1107-1112. https://doi.org/10.1093/jnci/82.13.1107

16. Yun LP, John C, Chih-Yuan H, Hoon KY (2012) Agarose gel electrophoresis for the separation of DNA fragments. JVis Exp 62:3923

17. Boom R, Sol CJ, Salimans MM, Jansen CL, Wertheim-van Dillen PM, van der Noordaa J (1990) Rapid and simple method for purification of nucleic acids. J Clin Microbiol 28(3):495-503

18. Chomczynski P, Sacchi N (1987) Single-step method of RNA isolation by acid guanidiniumthiocyanate-phenol-chloroform extraction. Anal Biochem 162(1):156-159. https://doi.org/10.1006/abio.1987.9999

19. Livak KJ, Schmittgen TD (2001) Analysis of relative gene expression data using real-time quantitative PCR and the 2 (-Delta DeltaC(T)). Methods 25(4):402-408. https://doi.org/10.1006/meth.2001

20. Zhang F, Shi J, Thakur K, Hu F, Zhang J, Wei Z (2017) Anti-cancerous potential of polysaccharide fractions extracted from peony seed dreg on various human cancer cell lines via cell cycle arrest and apoptosis. Front Pharmacol 8:102. https://doi.org/10.3389/fphar.2017.00102

21. Suna CP, Sunb D, Wanga X (2017) Effects of Scutellaria barbata polysaccharide on the proliferation, apoptosis and EMT of human colon cancer HT29 Cell. Carbohyd Polym 167:90-96

22. Lia C, Tiana Z, Caia J, Chena K, Zhangc B, Fenga M, Shia Q, Lic R, Qina Y, Genga J (2014) Panax ginseng polysaccharide induces apoptosis by targeting Twist/AKR1C2/NF-1 pathway in human gastric cancer. Carbohyd Polym 102:103-109

23. Jiao L, Li B, Wang M, Liua Z, Zhang X, Liu S (2014) Antioxidant activities of the oligosaccharides from the roots, flowers and leaves of Panax ginseng C.A. Meyer Carbohydr Polym 106:293-298. https://doi.org/10.1016/j. carbpol.2014.02.035

24. Mortezaee K, Salehi E, Mirtavoos-Mahyari H, Motevaseli E, Najafi M, Farhood B, Rosengren RJ, Sahebkar A (2019) Mechanisms of apoptosis modulation by curcumin: implications for cancer therapy. J Cell Physiol 234(8):12537-12550. https://doi.org/10.1002/jcp.28122

25. Agool A, Slart RH, Thorp KK, Glaudemans AW, Cobben DC, Been LB, Burlage FR, Elsinga PH, Dierckx RA, Vellenga E, Holter JL (2011) Effect of radiotherapy and chemotherapy on bone marrow activity: a $18 \mathrm{~F}$-FLT-PET study. Nucl Med Commun 32(1):17-22. https://doi.org/10.1097/mnm. ob013e328340798c
26. Deng Q, Huang CM, Chen N, Li L, Wang XD, Zhang W, Tang QL, Bi F, Li ZP, Wang W (2012) Chemotherapy and radiotherapy down regulate the activity and expression of DNA methyl transferase and enhance BCl-2/E1B-19-kDa interacting protein-3- induced apoptosis in human colorectal cancer cells. Chemotherapy 58(6):445-453. https://doi.org/ $10.1159 / 000345916$

27. Mortezaee K, Najafi M, Farhood B, Ahmadi A, Potes Y, Shabeeb D, Musa AE (2019) Modulation of apoptosis by melatonin for improving cancer treatment efficiency: an updated review. Life Sci 228:228-241. https:// doi.org/10.1016/j.lfs.2019.05.009

28. Collins JA, Schandi CA, Young KK, Vesely J, Willingham MC (1997) Major DNA fragmentation is a late event in apoptosis. J Histochem Cytochem 45(7):923-934. https://doi.org/10.1177/002215549704500702

29. Senturk E, Manfredi JJ (2013) p53 and cell cycle effects after DNA damage methods. Mol Biol 962:49-61. https://doi.org/10.1007/ 978-1-62703-236-0_4

30. Akcay NI, Bashirov R, Tuzmen S (2015) Validation of signaling pathways: case study of the p16-mediated pathway. J Bioinform Comput Biol 13(2):1550007. https://doi.org/10.1142/S0219720015500079

31. Kita R, Nishida N, Fukuda Y, Azechi H, Matsuoka Y, Komeda T, Sando T, Nakao K, Ishizaki K (1996) Infrequent alterations of the p16INK4A gene in liver cancer. Int J Cancer 67:176-180

32. Pulling LC, Klinge DM, Belinsky SA (2001) p16INK4a and beta-catenin alterations in rat liver tumors induced by NNK. Carcinogenesis 22:461-466

33. Ivanchuk SM, Mondal S, Dirks PB, Rutka JT (2001) The INK4A/ARF locus: role in cell cycle control and apoptosis and implications for glioma growth. J Neurooncol 51(3):219-229. https://doi.org/10.1023/a:10106 32309113

34. Rezaei PF, Fouladdel S, Ghaffari SM, Amin G, Azizi E (2012) Induction of $\mathrm{G} 1$ cell cycle arrest and cyclin D1 down-regulation in response to pericarp extract of Baneh in human breast cancer T47D cells. DARU J Pharm Sci 20(1):101. https://doi.org/10.1186/2008-2231-20-101

35. Holysz H, Lipinska N, Paszel-Jaworska A, Rubis B (2013) Telomerase as a useful target in cancer fighting - the breast cancer case. Tumor Biol 34(3):1371-1380

36. Rubis B, Holysz H, Gladych M, Toton E, Paszel A, Lisiak N, Kaczmarek M, Hofmann J, Rybczynska M (2013) Telomerase down regulation induces proapoptotic genes expression and initializes breast cancer cells apoptosis followed by DNA fragmentation in a cell type dependent manner. Mol Biol Rep 40:4995-5004

37. Pfeffer CM, Singh ATK (2018) Apoptosis: a target for anticancer therapy. Int J Mol Sci 19(2):448. https://doi.org/10.3390/ijms19020448

38. Yamada A, Arakaki R, Saito M, Kudo Y, Ishimaru N (2017) Dual role of Fas/FasL-mediated signal in peripheral immune tolerance. Front Immunol 8:403. https://doi.org/10.3389/fimmu.2017.00403

39. Gaumer S, Guénal I, Brun S, Théodore L, Mignotte B (2000) BCl-2 and Bax mammalian regulators of apoptosis are functional in Drosophila. Cell Death Differ 7(9):804-814

40. Zhu S, Li T, Tan J, Yan X, Zhang D, Zheng C, Chen Y, Xiang Z, Cui H (2012) Bax is essential for death receptor mediated apoptosis in human colon cancer cells. Cancer Biother Radiopharm 27(9):577-581

41. Moldoveanu T, Follis AV, Kriwacki RW, Green DR (2014) Many players in BCL-2 family affairs. Trends Biochem Sci 39(3):101-111

42. Gao Y, Gao H, Chan E, Tang W, Xu A, Yang H, Huang M, Lan X, Li J, Duan W, Xu C, Zhou S (2005) Antitumor activity and underlying mechanisms of ganopoly, the refined polysaccharides extracted from Ganodermalucidum, in mice. Immunol Invest 34(2):171-198

43. Sinha K, Das J, Pal PB, Sil PC (2013) Oxidative stress: the mitochondria dependent and mitochondria-independent pathways of apoptosis. Arch Toxicol 87:1157-1180. https://doi.org/10.1007/s00204-013-1034-4

44 Schulz R, Moll UM (2014) Targeting the heat shock protein 90: a rational way to inhibit macrophage migration inhibitory factor function in cancer. Curr Opin Oncol 26(1):108-113. https://doi.org/10.1097/CCO. 0000000000000036

45 Principe DR, Doll JA, Bauer J, Jung B, Munshi HG, Bartholin L, Pasche B, Lee C, Grippo PJ (2014) TGF- $\beta$ : duality of function between tumor prevention and carcinogenesis. J Natl Cancer Inst 106(2):369. https:// doi.org/10.1093/jnci/djt369

46. Lee S, Margolin K (2011) Cytokines in cancer immunotherapy. Cancers 3(4):3856-3893. https://doi.org/10.3390/cancers3043856 
47 Wang $X$, Lin Y (2008) Tumor necrosis factor and cancer, buddies or foes? Acta Pharmacol Sin 29(11):1275-1288

48. Ham B, Fernandez MC, D'Costa Z, Brodt P (2016) The diverse roles of the TNF axis in cancer progression and metastasis. Trends Cancer Res 11(1):1-27

49. Sun LX, Lin ZB, Duan XS, Lu J, Ge ZH, Li XJ, Li M, Xing EH, Jia J, Lan TF, Li WD (2011) Ganodermalucidum polysaccharides antagonize the suppression on lymphocytes induced by culture supernatants of B16F10 melanoma cells. J Pharm Pharmacol 63:725-735

50. Schon $H$, Weiskirchen $R$ (2014) Immuno modulatory effects of transforming growth factor- $\beta$ in the liver Hepatobiliary. Surg Nutr 3(6):386-406
51. Wang X, Ding J, Feng Y, Weng L, Zhao G, Xiang J, Zhang M, Xing D (2017) Targeting of growth factors in the treatment of hepatocellular carcinoma: the potentials of polysaccharides. Oncol Lett 13(3):1509-1517. https:// doi.org/10.3892/ol.2017.5602

\section{Publisher's Note}

Springer Nature remains neutral with regard to jurisdictional claims in published maps and institutional affiliations.

\section{Submit your manuscript to a SpringerOpen ${ }^{\circ}$ journal and benefit from:}

- Convenient online submission

- Rigorous peer review

- Open access: articles freely available online

- High visibility within the field

- Retaining the copyright to your article

Submit your next manuscript at $\boldsymbol{\nabla}$ springeropen.com 